\title{
Metallo-stannosilicates as inorganic supports to immobilization of lipase from Thermomyces lanuginosus for biodiesel production
}

\author{
Danilo Antonio da Silva ${ }^{1} \oplus$, Adriano de $\operatorname{Vasconcellos}^{1}{ }^{\oplus}$, José Geraldo Nery $^{1+}{ }^{\oplus}$
}

1. São Paulo State University, Institute of Biosciences, Letters and Exact Sciences, São José Rio Preto, Brazil.

+Corresponding author: José Geraldo Nery, Phone: +55 17 3221-2490, Email address: geraldo.nery@unesp.br

\section{ARTICLE INFO}

Article history:

Received: September 08, 2020

Accepted: February 10, 2021

Published: April xx, 2021
Keywords

1. Stannosilicates

2. biofuels

3. heterogeneous catalysts

4. enzymes immobilization

5. enzymatic catalysis

ABSTRACT: This study reports the application of metallo-stannosilicates as potential inorganic solid matrixes for enzymes immobilization and their use as a heterogenous catalysts in enzymatic transesterification reactions for the conversion of triacylglycerides into fatty acid ethyl esters (FAEEs). Several stannosilicates were synthesized and physicochemical characterized by X-ray powder diffraction (XRD), scanning electron microscopy with energy dispersive X-ray spectrometry (SEMEDS), Brunauer-Emmett-Teller (BET)- $\mathrm{N}_{2}$ surface area analysis and solid-state magic-angle spinning nuclear magnetic resonance (MAS NMR ${ }^{29} \mathrm{Si}$ and ${ }^{119} \mathrm{Sn}$ nuclei) techniques. The experimental results for enzymes immobilization were promising, especially for a nickel ion-exchanged metallostannosilicate, which were able to immobilize $82 \pm$

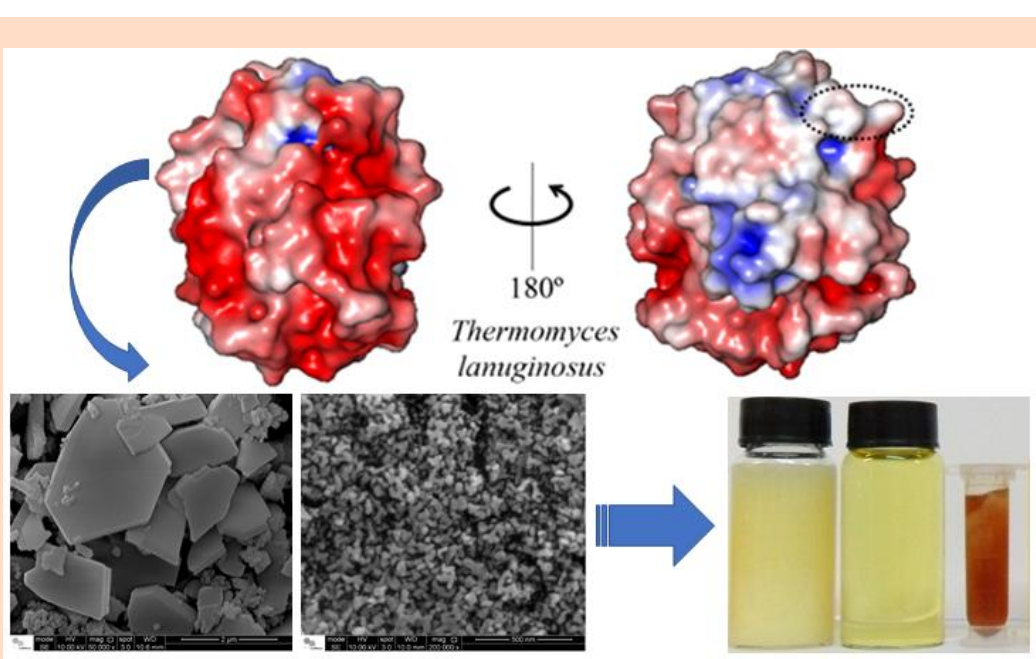

Metallo-stannosilicates as inorganic supports for enzymes immobilization Synergistic effect $=82 \pm 6 \%$ of enzymes and $63.3 \pm 0.7 \%$ of FAEEs yield $6 \%$ of Thermomyces lanuginosus lipase and also kept a high enzymatic activity $\left(42 \pm 3 \mathrm{U} \mathrm{mg}^{-1}\right)$. Systematic catalytic reactions for conversion of refined palm oil (Elaeis guineensis) using some of these stannosilicates enzymes complexes yielded $63.3 \pm 0.7 \%$ of FAEEs. It is worth noticing that, when the transesterification reaction was performed with (a) the as-made stannosilicate without enzymes and (b) the equivalent amount of immobilized Thermomyces lanuginosus lipase in its free form, the FAEEs yield sharply decreased to $<5.0 \%$ and $6.3 \pm 0.3 \%$, respectively. This result is a clear evidence of a synergistic effect among the metallo-stannosilicates and the immobilized enzymes. 


\section{Introduction}

The development of alternative biofuels as viable ways to replace or reduce the use of fossil fuels has stimulated the efforts of the scientific community. The energy demand arises from numerous factors, including environmental concerns and the depletion of fossil fuel resources that have stimulated the development of new alternative sources of more sustainable fuels. Among the various options, biodiesel is attractive because it is a sustainable and renewable form of energy ${ }^{1}$. Chemically, biodiesel consists of a mixture of fatty acid alkyl esters (FAAEs) and is predominantly produced, in industrial scale, by means of transesterification reactions using refined vegetable oils as triacylglycerides sources, together with short chain alcohols (methanol or ethanol) and homogeneous catalysts. The appropriate choice of triacylglycerides feedstocks and catalysts are the main challenges and have precluded a faster development of this industry.

Concerning the available triacylglycerides sources, the use of edible oils has raised ethical and economic questions, one of the reasons to search alternative lipid feedstocks that do not compete with food production ${ }^{2,3}$. There are several lipids feedstocks for biodiesel production, such as: palm, castor, soybean, cotton, peanuts, jatropha, sunflower (vegetable oils), besides the utilization of animal fats, nonedible and waste oils. Considering oils from vegetable origin, the palm tree (Elaeis guineensis) is an excellent option due of its low price, relatively high oil content (palm fruit contains approximately $40 \%$ of oil) and high productivity (2500-4000 kg hectare ${ }^{-1}$ year $\left.^{-1}\right)$. Furthermore, palm oil is more saturated and has greater oxidation stability when compared to other vegetable oils, in addition to being an important alternative for the sustainable development of some Brazilian regions, mainly in the Amazon $^{4,5}$. Another important component in the biodiesel production process is the short chain alcohol source. In Brazil, the use of ethanol is a viable option, since the country is the world's second largest producer of ethanol. However, most industrial biodiesel plants do not have the technology to synthesize biodiesel by applying ethanol as a solvent, since that the production of biodiesel via the ethylic route presents some obstacles, such as high alcohol consumption and difficulty in separating the final products (glycerol and biodiesel), which generates greater energy costs for this process.

In terms of catalyst technology, sodium hydroxide $(\mathrm{NaOH})$, potassium hydroxide $(\mathrm{KOH})$ and sodium methoxide $\left(\mathrm{NaOCH}_{3}\right)$ are currently the main homogeneous catalysts employed in the biodiesel industry. Their disadvantages are associated with the impossibility of use low-quality feedstocks, with high contents of water and free fatty acids (FFAs) ${ }^{6}$. Although not currently applied in industrial scale for biodiesel production, heterogeneous acid catalysts could be an interesting alternative to solve this problem due the fact of being less sensitive to FFAs content and perform simultaneously the esterification and transesterification reactions. Moreover, the heterogeneous catalyst can be recycled (reused), there is none or very little amount of wastewater produced during the catalytic process and the separation of the catalysts from biodiesel and glycerol is relatively easy. Nevertheless, its application in the biodiesel industry is preclude due the necessity of employing longer reaction times, higher reaction temperatures and large alcohol to oil molar ratios ${ }^{7-10}$. The combination of all these factors has a negative impact in the final price of the biodiesel, therefore the search for new heterogeneous catalysts able to overcome these drawbacks is a technical and scientific challenge.

Zeolites and Mixed Octahedral-PentahedralTetrahedral Silicates (OPT) materials are inorganic microporous framework oxides and can be an interesting option to overcome these challenges. Mixed framework OPT materials containing coordinated tetrahedra or octahedra, namely stannosilicates, is one of these materials subject of research. Stannosilicates and tin-zeotypes materials have been reported as ion exchangers, sorbents and catalysts for several types of reaction, as purification of natural gas with sulfur compounds, like hydrogen sulfides or oxysulfides ${ }^{11}$, and catalytic reactions for decomposition of propan-2$\mathrm{ol}$ and oxidation of cyclohexene ${ }^{12}$, Baeyer-Villiger oxidation reaction $\mathrm{s}^{13}$, monosaccharide isomerization reactions ${ }^{14,15}$ and application as heterogeneous catalysts for biofuels production ${ }^{16}$. Tin-based homogeneous and heterogeneous catalysts have been used in transesterification reactions, mainly using refined edible oils as feedstocks and methanol, typically providing high yields of fatty acid methyl esters (FAMEs) $^{17-24}$.

The use of lipases (triacylglycerol acylhydrolases, E.C.3.1.1.3) as catalysts in the biodiesel production is also an attractive option due to their high specificity for the transesterification of triacylglycerides to FAMEs or FAEEs in comparison with the other conventional chemical catalysts employed in industrial biodiesel production. In comparison to the basic homogeneous catalysts, enzymes exhibit high selectivity and catalytic activity under mild operative conditions. In addition, lipases can also catalyze the transesterification of waste feedstocks that contain a high content of free fatty 
acids (FFAs) and water, therefore decreasing the probability of forming soap and emulsion ${ }^{25}$. Some examples of biodiesel production by enzymatic catalysis are the transesterification of soybean oil (Glycine max) by applying different lipases and experimental parameters (quantity of biocatalyst, reaction time, amount of water added and turnover of lipases) $)^{26-28}$, esterification reactions of oleic acid ${ }^{29}$ and FAEEs production by enzymatic transesterification of triolein $^{30}$. Besides all the advantages of the enzymatic process in comparison to the other ones, there are important drawbacks that preclude their large use in industrial scale process for biodiesel production. Between them are the enzymes expensive costs, the difficulty of its separation (recover of the enzymes and reuse in its free form), besides the possible deactivation of enzymes active sites by glycerol, a subproduct of triacylglycerides transesterification. In this context, the enzymes immobilization is a viable alternative for overcoming these obstacles ${ }^{31-36}$.

The use of supports for enzymatic immobilization is an effective way to combine the advantages of both heterogeneous and enzymatic catalysts. Enzymatic immobilization consists of locating or confining an enzyme on a solid support or matrix. The methods are basically classified as chemical or physical processes, and the choice of the appropriate support depends of physical-chemical characteristics, such as mechanical, chemical and microbial resistance, thermal stability, high loading capacity, adequate pore diameter and hydrophilic/hydrophobic behavior that allows the immobilization of the enzymes ${ }^{37}$. Several solid materials, such as ceramics, kaolinites, silica, cellulose, polymers and zeolites, have been used as supports for enzymes immobilization. Specifically, in the case of zeolites and mixed framework oxides, the aim of the immobilization is to create a zeolite-enzyme complex that can be applied as biocatalysts. It is clear from these studies ${ }^{38-40}$ that both the zeolites and the enzymes can themselves alone catalyze the transesterification reaction: each one of them have their own particularity that determines the rate and yield of the final product.

This study is a sequence of previous work reported by the authors research group ${ }^{16}$ concerning the application of a metallo-stannosilicate for biodiesel production using edible, nonedible and waste oils as feedstocks. In this paper, several stannosilicates were synthesized using different sol-gel chemical compositions. The stannosilicates were physicochemical characterized and, afterwards, used as heterogeneous catalysts in the transesterification of refined palm oil (Elaeis guineensis) by ethanolysis reactions. Furthermore, these materials were also studied as potential inorganic solid matrixes for immobilization of Thermomyces lanuginosus lipase and tested in enzymatic transesterification reactions with the following aims: are metallo-stannosilicates feasible for use as inorganic supports for enzymes immobilization? What can be learned from catalytic results about the appropriated application of different catalysts in specific reactions for biodiesel production?

To the best our knowledge, metallo-stannosilicates were not previously explored as inorganic supports for enzymes immobilization and as heterogeneous catalysts in enzymatic transesterification reactions for biodiesel production by applying the feedstocks (refined palm oil and ethanol) used in this work.

\section{Experimental}

\subsection{Materials}

The syntheses of the metallo-stannosilicates, the nickel ion-exchange experiments, the catalytic reactions for biodiesel production and the enzymes immobilization reactions employed the following chemicals: Ludox HS-40 colloidal silica (40 wt.\% $\mathrm{SiO}_{2}$ in water), tin chloride pentahydrate $\left(\mathrm{SnCl}_{4} \cdot 5 \mathrm{H}_{2} \mathrm{O}\right.$, $98 \%)$, sodium hydroxide $(\mathrm{NaOH})$, potassium hydroxide $(\mathrm{KOH})$, nickel(II) sulfate hexahydrate $\left(\mathrm{NiSO}_{4} \bullet 6 \mathrm{H}_{2} \mathrm{O}\right.$, 98\%), Bradford reagent (1-1,400 $\mu \mathrm{g}$ $\mathrm{mL}^{-1}$ protein) and enzyme lipolase $100 \mathrm{~L}$ (from Thermomyces lanuginosus lipase, molecular weight 30 $\mathrm{kDa}$, pI 4.4, solution $\geq 100,000 \mathrm{U} \mathrm{g}^{-1}$ ) were purchased from Sigma-Aldrich (Steinheim, Germany) and used as received, without further purification.

The Thermomyces lanuginosus is a purified enzyme 1,3-specific lipases (EC 3.1.1.3) and industrially produced through the submerged fermentation of a genetically modified Aspergillus oryzae fungus ${ }^{41}$. This lipase was used based on satisfactory results reported by our research group ${ }^{35,36}$ among other examples of application of this enzyme to biodiesel production ${ }^{42-44}$. Anhydrous ethyl alcohol (99.8\%) was purchased from Dinâmica Chemistry (Diadema, Brazil). The refined palm oil (Elaeis guineensis) predominantly composed by palmitic acid (C16), stearic acid (C18), oleic acid (C18:1) and linoleic acid (C18:2) were obtained from Agropalma Company (Belém, Brazil). The gas chromatogram (GC-FID), which illustrates these major components in the oil composition, is illustrated and discussed in the supplementary material. 


\subsection{Hydrothermal syntheses of stannosilicates}

The stannosilicates were synthesized according to experimental procedures adapted from the literature ${ }^{45,46}$ by hydrothermal crystallization in the $\mathrm{Na}_{2} \mathrm{O}-\mathrm{SnO}_{2}-\mathrm{SiO}_{2}$ oxides system. Detailed experimental conditions of all the stannosilicates synthesized are summarized in Tab. 1. A typical synthesis for the material named stannosilicate I, using $\mathrm{Sn}^{4+}\left(\mathrm{SnCl}_{4} \cdot 5 \mathrm{H}_{2} \mathrm{O}\right.$ as the tin source) and gel composition of $1 \mathrm{Na}_{2} \mathrm{O}: \mathrm{SnO}_{2}: 4 \mathrm{SiO}_{2}: 80 \mathrm{H}_{2} \mathrm{O}$ was performed at the following manner: $14.9 \mathrm{~g}$ of sodium hydroxide $(\mathrm{NaOH})$ was dissolved in $20 \mathrm{~g}$ of water (solution A). A second solution (solution B) was prepared by dissolving $20 \mathrm{~g}$ of $\mathrm{SnCl}_{4} \cdot 5 \mathrm{H}_{2} \mathrm{O}$ in $30 \mathrm{~g}$ of distilled water. This solution $\mathrm{B}$ was added to the solution $\mathrm{A}$ and homogenized under $500 \mathrm{rpm}$ of stirring during $60 \mathrm{~min}$ at $25{ }^{\circ} \mathrm{C}$ of temperature (solution C). Finally, solution $\mathrm{C}$ was added to $27.4 \mathrm{~g}$ of Ludox HS-40 colloidal silica (40 wt.\% $\mathrm{SiO}_{2}$ in water) and this final gel was also kept stirring for $30 \mathrm{~min}$ at $500 \mathrm{rpm}$. The sol-gel solution was transferred to a $125 \mathrm{~mL}$ teflon-lined stainless-steel autoclave (Parr Instruments Co., Illinois, USA) and kept at $200{ }^{\circ} \mathrm{C}$ for 7 days. Afterwards, the reactor was cooled down, the product collected by filtration, washed with distilled water and dried at $100{ }^{\circ} \mathrm{C}$ for $12 \mathrm{~h}$.

Table 1. Summary of the experimental procedures for the metallo-stannosilicates syntheses.

\begin{tabular}{|c|c|c|c|c|c|c|c|c|c|}
\hline \multirow{2}{*}{$\begin{array}{l}\text { Gel } \\
\text { composition }\end{array}$} & \multirow[t]{2}{*}{ Nomenclature } & \multicolumn{2}{|c|}{ Step 1 (solution A) } & \multicolumn{2}{|c|}{ Step 2 (solution B) } & \multirow[t]{2}{*}{$\begin{array}{c}\text { Step } 3 \text { (solution } \\
C)^{* *+* * *}\end{array}$} & \multirow{2}{*}{$\begin{array}{l}\text { Step } 4 \text { Ludox } \\
\text { HS-40 / } g\end{array}$} & \multirow{2}{*}{$\begin{array}{c}\text { Step } 5 \text { (final } \\
\text { gel) })^{* * * * *}\end{array}$} & \multirow{2}{*}{$\begin{array}{l}\text { Surface area } \\
\qquad / m^{2} g^{-1}\end{array}$} \\
\hline & & $\mathrm{NaOH} / \mathrm{g}$ & $\mathrm{H}_{2} \mathrm{O} / \mathrm{g}$ & $\mathrm{SnCl}_{4} \cdot 5 \mathrm{H}_{2} \mathrm{O} / \mathrm{g}$ & $\mathrm{H}_{2} \mathrm{O} / \mathrm{g}$ & & & & \\
\hline $\begin{array}{l}1 \mathrm{Na}_{2} \mathrm{O}: \mathrm{SnO}_{2}: 4 \\
\mathrm{SiO}_{2}: 80 \mathrm{H}_{2} \mathrm{O}\end{array}$ & $I^{*}$ & 14.9 & 20.0 & 20.0 & 30.0 & \multirow{4}{*}{$\begin{array}{c}\text { Add solution } B \text { to } \\
\text { solution } A\end{array}$} & 27.4 & \multirow{5}{*}{$\begin{array}{c}\text { Add solution } \\
\text { C to Ludox } \\
\text { HS-40 }\end{array}$} & 18.73 \\
\hline $\begin{array}{l}2 \mathrm{Na}_{2} \mathrm{O}: \mathrm{SnO}_{2}: 4 \\
\mathrm{SiO}_{2}: 80 \mathrm{H}_{2} \mathrm{O}\end{array}$ & $\mathrm{II}^{*}$ & 29.8 & 20.0 & 20.0 & 30.0 & & 27.4 & & 22.40 \\
\hline $\begin{array}{l}1 \mathrm{Na}_{2} \mathrm{O}: \mathrm{SnO}_{2}: 1 \\
0 \mathrm{SiO}_{2}: 80 \mathrm{H}_{2} \mathrm{O}\end{array}$ & III** & 4.2 & 10.0 & 16.0 & 22.0 & & 54.8 & & 86.95 \\
\hline $\begin{array}{l}2 \mathrm{Na}_{2} \mathrm{O}: \mathrm{SnO}_{2}: 1 \\
0 \mathrm{SiO}_{2}: 80 \mathrm{H}_{2} \mathrm{O}\end{array}$ & $\mathrm{IV}^{* *}$ & 8.4 & 10.0 & 16.0 & 22.0 & & 54.8 & & 50.45 \\
\hline $\begin{array}{l}5 \mathrm{Na}_{2} \mathrm{O}: \mathrm{SnO}_{2}: 1 \\
0 \mathrm{SiO}_{2}: 80 \mathrm{H}_{2} \mathrm{O}\end{array}$ & $\mathrm{V}^{* *}$ & 21.1 & 20.0 & 16.0 & --- & $\begin{array}{c}\text { Add } \mathrm{SnCl}_{4} \cdot 5 \mathrm{H}_{2} \mathrm{O} \\
\text { in solution }\end{array}$ & 54.9 & & 8.16 \\
\hline
\end{tabular}

$*$ Time of hydrothermal synthesis $=7$ days; $* *$ Time of hydrothermal synthesis $=21$ days; $* * *$ The gel was homogenized at 500 rpm for $60 \mathrm{~min}$ at ambient temperature of $25^{\circ} \mathrm{C}$.

\subsection{Nickel ion-exchange experiments}

Prior to the enzyme immobilization, all stannosilicates synthesized were subjected to nickel ion-exchange experiments. The experiments were made as follows: $30 \mathrm{~mL}$ of $0.5 \mathrm{~mol} \mathrm{~L}^{-1} \mathrm{NiSO}_{4}$ solution (3.94 g of $\mathrm{NiSO}_{4} \cdot 6 \mathrm{H}_{2} \mathrm{O}$ was dissolved in $30 \mathrm{~mL}$ of distilled water) was added into a teflon bottle. Afterwards, $1 \mathrm{~g}$ of the stannosilicates was added to this solution and kept stirring at $500 \mathrm{rpm}$ for $60 \mathrm{~min}$ and $25^{\circ} \mathrm{C}$ of temperature. Afterwards, the solution was heated at $80{ }^{\circ} \mathrm{C}$ for $24 \mathrm{~h}$. After this period, the nickelstannosilicates were cooled down, collected by filtration, washed with distilled water and dried at $100{ }^{\circ} \mathrm{C}$ for $12 \mathrm{~h}$.

\subsection{Physicochemical characterization of the solid materials}

\subsubsection{X-ray diffraction, BET-N2 surface area and SEM-EDS}

All the stannosilicates synthesized were characterized by XRD using a Rigaku Miniflex
(Rigaku, Tokyo, Japan) operated at $40 \mathrm{kV}, 15 \mathrm{~mA}$ and using a Ni-filtered $\mathrm{Cu}-\mathrm{K} \alpha$ radiation $(\lambda=1.5418 \AA)$ in the range of $2 \theta$ from 3 to $80^{\circ}$ with goniometer rate of $2^{\circ}(2 \theta) \mathrm{min}^{-1}$. Surface area measurements at $77 \mathrm{~K}$ were performed on a Micromeritics ASAP 2020 (Micrometrics Instrument Corporation, Norcross, USA) using the facilities of the BAM Federal Institute for Materials Research and Testing (Division 1.3. Structural Analysis, Berlin, Germany). Prior to the measurement, all samples were degassed at temperature of $300{ }^{\circ} \mathrm{C}$ and pressure of $5 \times 10^{-5} \mathrm{mbar}$ for $3 \mathrm{~h}$, and isotherms were processed by the BET (Brunauer-Emmett-Teller) method $^{47}$. Scanning electron microscopy (SEM) and energy-dispersive Xray spectrometry (EDS) results were recorded on a FEI Inspect F50 (FEI Instruments, Oregon, USA) using the facilities of the Brazilian National Laboratory of Nanotechnology (LNNano, Electron Microscopy Laboratory, Campinas, Brazil). The electronic microscope is equipped with a Schottky field emission source, probe current at $200 \mathrm{nA}$ and an electron beam with accelerating voltages between 0.2 and $30 \mathrm{kV}$. 


\subsubsection{Solid-state MAS NMR}

Solid-state magic angle spinning NMR (MAS NMR) experiments were performed using the facilities of the BAM Federal Institute for Materials Research and Testing (Division 1.3. Structural Analysis, Berlin, Germany). The fully hydrated metallo-stannosilicates samples were characterized by ${ }^{29} \mathrm{Si}$ and ${ }^{119} \mathrm{Sn}$ SinglePulse MAS NMR using a Bruker Avance 400 spectrometer $(9.4 \mathrm{~T})$. The data were analyzed and processed in the software TopSpin 3.6.2 version. All the experiments were carried out at room temperature and the samples were filled into zirconia rotors equipped with Kel-F caps (Bruker, Wissembourg, France) of 7 and $4 \mathrm{~mm}$ for ${ }^{29} \mathrm{Si}$ and ${ }^{119} \mathrm{Sn}$ nuclei, respectively. The ${ }^{29} \mathrm{Si}$ single-pulse MAS NMR spectra were obtained using radiofrequency pulses at the Larmor frequency of $79.5 \mathrm{MHz}$, MAS frequency of 6.5 $\mathrm{kHz}, 90^{\circ}$ pulse length of $6.0 \mu \mathrm{s}$ and recycle delay of 300 s. ${ }^{1} \mathrm{H}\left\{{ }^{29} \mathrm{Si}\right\}$ cross-polarization (CPMAS) experiments were also made by applying $90^{\circ}$ pulse of $3.0 \mu \mathrm{s}$, cross-polarization time of $6.0 \mathrm{~ms}$ and repetition time of $3.0 \mathrm{~s}$ were used in order to maximize ${ }^{29} \mathrm{Si}$ signal intensities. A 50\% amplitude CP ramp and TPPM15 (decoupling power level is the same as for the $90^{\circ}{ }^{1} \mathrm{H}$ pulse of $3.0 \mu \mathrm{s}$ ) was also applied. The ${ }^{29} \mathrm{Si}$ chemical shifts were reported relative to kaolinite as secondary reference $(\delta=-91.5 \mathrm{ppm})$. The ${ }^{119} \mathrm{Sn}$ single-pulse MAS NMR spectra were obtained using radiofrequency pulses at the Larmor frequency of $149.1 \mathrm{MHz}$, MAS frequency of $12.5 \mathrm{kHz}, 90^{\circ}$ pulse length of $2.5 \mu \mathrm{s}$ and recycle delay of $600 \mathrm{~s}$. The ${ }^{119} \mathrm{Sn}$ chemical shifts were reported relative to $\mathrm{SnO}_{2}$ $(\delta=-604 \mathrm{ppm})^{48}$.

\subsubsection{Zeta potential of the stannosilicates and stannosilicates-lipases complexes}

The zeta potential of the stannosilicates and stannosilicates-enzymes complexes were measured in a Nano Zetasizer ZS90 equipment (Malvern Instruments, Worcester Shire, UK). Prior to the measurements, $1 \mathrm{mg}$ of the materials and $1 \mathrm{~mL}$ of deionized water were placed in Eppendorf tubes and stabilized during $30 \mathrm{~min}$ at $25{ }^{\circ} \mathrm{C}$, and then transferred to a DTS1060 cell, equipped with golden electrodes. A wide angle $\left(90^{\circ}\right)$ laser Doppler velocimetry was used to measure the electrophoretic mobility and the $\zeta$ potential (zeta potential), expressed in $\mathrm{mV}$, was calculated by Smoluchowski equation ${ }^{49}$.

\subsection{Enzymes immobilization on the stannosilicates}

The enzymes immobilization experiments were made in triplicate, according to adapted procedures from the literature ${ }^{35,50}$. The initial concentration of $2 \mathrm{mg} \mathrm{mL}^{-1}$ of the commercial lipases (enzyme Lipolase $100 \mathrm{~L}$, from Thermomyces lanuginosus lipase) was added in a phosphate buffer solution, $20 \mathrm{mmol} \mathrm{L}^{-1}$ and $\mathrm{pH} 7$, according to a proportion of 1:40 $(25 \mu \mathrm{L}$ of commercial lipase: $1 \mathrm{~mL}$ phosphate buffer:50 $\mathrm{mg}$ of stannosilicates) and stirred at $300 \mathrm{rpm}$ for $16 \mathrm{~h}$ at room temperature of $25{ }^{\circ} \mathrm{C}$, followed by the separation of stannosilicates-lipases complexes via centrifugation at $12,000 \mathrm{rpm}$ for $1 \mathrm{~min}$. The products were washed twice with deionized water, dried at $25{ }^{\circ} \mathrm{C}$ overnight and stored at $4{ }^{\circ} \mathrm{C}$. The amount of the enzymes immobilized was determined according to proposed by Bradford $^{51}$ and based on procedures adapted from the literature ${ }^{52}$.

\subsection{Determination of percentual of enzymes immobilized on the stannosilicates}

The percentual of Thermomyces lanuginosus lipase immobilized on the stannosilicates supports were determined by the method described Bradford ${ }^{46}$, which uses bovine serum albumin as standard and its absorption in the ultraviolet wavelength $(\lambda=595 \mathrm{~nm})$. For these measurements, three different solutions were prepared, previously the measurements: (a) supernatant solution that remain after the enzymes immobilization reactions, (b) a solution with the same quantity of enzymes prepared for the immobilization reaction, diluted in the phosphate buffer solution $(20 \mathrm{mM}$ and $\mathrm{pH} 7$ ) and (c) only the same amount of the phosphate buffer solution, which has its absorbance subtracted of the other solutions. Afterwards, a mixture of Bradford

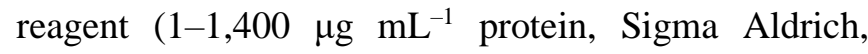
Germany) and the samples described above were mixed in the proportion of $1: 20 \quad(50 \mu \mathrm{L}$ of solution: $950 \mu \mathrm{L}$ of Bradford reagent) and kept out of the luminosity for $20 \mathrm{~min}$. The percentage of enzymes immobilized was calculated from the relationship ${ }^{52}$ shown in Eq. 1:

$\%$ enzymes immobilized $=$

$\frac{\text { initial amount of enzymes (solution } b \text { )-amountof enzymes after immobilization (solution a) }}{\text { initial amount of enzymes (solution } b \text { ) }} \times 100$ 


\subsection{Enzymatic hydrolytic activity stannosilicates-enzymes complexes}

The enzymatic hydrolytic activity of stannosilicateenzymes complexes was determined by titrimetric method $^{35,53}$ and following ACS specifications in the sigma standard enzymatic assays for lipases (triacylglycerol acylhydrolases, E.C.3.1.1.3). Since that, the enzymatic activity is obtained by a hydrolysis reaction, one unit of lipase activity was defined as the amount stannosilicate-enzymes complexes releasing one mole of FFAs from a triacylglyceride source in $1 \mathrm{~h}$ of reaction at $40 \pm 2{ }^{\circ} \mathrm{C}$, expressed by the unity of $\mathrm{U} \mathrm{mg}^{-1}$ (unit of lipase activity/mg of stannosilicateenzymes complexes). In a typical measurement, $10 \mathrm{~mL}$ of a mixture containing $20 \mathrm{mmol} \mathrm{L}^{-1}$ at $\mathrm{pH} 7$ of phosphate buffer and a triacylglyceride substrate (refined soybean oil, Glycine max) was prepared in the volume proportion of 1:1.

This solution was thoroughly mixed and equilibrated at $37{ }^{\circ} \mathrm{C}$. Afterwards, $30 \mathrm{mg}$ of the stannosilicates-enzymes complexes was added and the reaction maintained at $37^{\circ} \mathrm{C}$ for $30 \mathrm{~min}$. Finally, the reaction was quenched by adding $3 \mathrm{~mL}$ of ethanol (95\%, Sigma Aldrich, Steinheim, Germany) and then cooled to the temperature of $-4{ }^{\circ} \mathrm{C}$ by using a mixture of ice and ethanol for $10 \mathrm{~min}$. The solution was centrifuged at $12,000 \mathrm{rpm}$ for $1 \mathrm{~min}$ and the FFAs obtained as a result of the enzymatic hydrolysis reaction were neutralized by a titration with a solution of $50 \mathrm{mmol} \mathrm{L^{-1 }} \mathrm{NaOH}$ in the presence of thymolphthalein as indicator. One unit of stannosilicate-enzymes activity was expressed as micro equivalents of FFAs released from the triacylglyceride substrate in $1 \mathrm{~h}$ at $37^{\circ} \mathrm{C}$, calculated according to Eq. 2:

$\frac{\text { Units }}{m g}$ solid $=\frac{(\mathrm{NaOH})(\text { Molarity of } \mathrm{NaOH})(1000)(2)}{\text { mass of the solid }}$

$\mathrm{NaOH}=$ volume $(\mathrm{mL})$

$1000=$ conversion factor from $10^{-3}$ equivalents to $10^{-6}$ equivalents

2 = time conversion factor from $30 \mathrm{~min}$ to $1 \mathrm{~h}$ (unit definition)

Mass of the solid $=$ mass $(\mathrm{mg})$ of stannosilicate-lipase complexes used in the hydrolysis reaction

\subsection{Enzymatic transesterification of refined palm oil (Elaeis guineensis) for FAEEs production}

Enzymatic transesterification of refined palm oil (Elaeis guineensis) by ethanolysis reaction catalyzed by free enzymes and stannosilicate-enzymes complexes were performed in $10 \mathrm{~mL}$ flasks, with an oil:ethanol ratio of 1:4, 3\% of stannosilicates-enzymes complexes referred to the oil mass and temperature of $40 \pm 2{ }^{\circ} \mathrm{C}$ for $48 \mathrm{~h}$. In order to avoid the inactivation of the enzymes, the total amount of ethanol was equally divided and added stepwise over four different time intervals $(0,3,6$ and $12 \mathrm{~h}$ after the start of the reaction). Afterwards, FAEEs and glycerol were separated by centrifugation at 12,000 rpm for $1 \mathrm{~min}$.

\subsection{Heterogeneous transesterification of refined palm oil (Elaeis guineensis) for FAEEs production}

Syntheses of FAEEs through the heterogeneous transesterification reactions were performed in triplicate (as performed for the enzymatic transesterification reactions) using refined palm oil (Elaeis guineensis) as triacylglycerides feedstock. In a typical transesterification reaction, $20.0 \mathrm{~g}$ of refined palm oil (FFAs content $=0.3 \mathrm{wt} . \%$, acid value of $0.6 \mathrm{mg} \mathrm{KOH} \mathrm{g}^{-1}$ ) was added in a $100 \mathrm{~mL}$ open glass reactor (catalytic reaction made at atmosphere pressure) with a reflux condenser, in a thermostatic bath equipped with a magnetic stirrer. Anhydrous ethyl alcohol was added according to alcohol:oil molar ratio of 1:30. The appropriate amount of catalyst (3\% of heterogeneous catalyst referred to oil mass) was added and the mixture heated at $100{ }^{\circ} \mathrm{C}$ for $12 \mathrm{~h}$, magnetic stirrer was set at $900 \mathrm{rpm}$ and the reflux temperature adjusted of $10 \pm 2{ }^{\circ} \mathrm{C}$. After the reaction time, the mixture was filtered, the excess of alcohol was removed using a rotary evaporator (Büchi Rotavapor R-210, Flawil, Switzerland) and glycerol were separated by centrifugation at 12,000 rpm for $1 \mathrm{~min}$.

\subsection{Quantification of FAEEs yields by gas chromatography (GC-FID)}

The measurements of FAEEs yields were made under the following experimental conditions: the measurements were made in a gas chromatograph (PerkinElmer, Massachusetts, USA) using a sample injection volume of $1 \mathrm{~mL}$, helium as gas carrier at a flow rate of $2 \mathrm{~mL} \mathrm{~min}^{-1}$ and pressure of $83 \mathrm{kPa}$, injector and detector temperatures of $250{ }^{\circ} \mathrm{C}$. The oven temperature started at $50^{\circ} \mathrm{C}$ for $1 \mathrm{~min}$, increased up to $250{ }^{\circ} \mathrm{C}$ at a rate of $5{ }^{\circ} \mathrm{C} \mathrm{min}^{-1}$. In a typical measurement, solutions of $20 \mathrm{mg} \mathrm{mL} \mathrm{m}^{-1}$ of the ethyl myristate (C14:0) and ethyl nervonate (C24:1) standards were prepared. Additionally, an ethylic nonadecanoate standard solution was prepared in a 
concentration of $10 \mathrm{mg} \mathrm{mL}{ }^{-1}$. The range of peaks integration were identified using the ethyl ester standards C14:0, C24:1 and an ethylic ester (C19:0) as the internal standard (IS). The FAEEs contents were obtained by integrating the peak areas from $\mathrm{C} 14: 0$ to C24:1 and subtracting the nonadecanoate area, according to Eq. 3:

$C=\frac{\sum A-A_{I S}}{A_{I S}} x \frac{C_{I S}-V_{I S}}{m} \times 100 \%$

$\sum \mathrm{A}=$ sum of the areas of all peaks ranging from $\mathrm{C} 14: 0$ and $\mathrm{C} 24: 0$

AIS $=$ C19:0 internal standard area

CIS $=$ concentration $\left(\mathrm{mg} \mathrm{mL}^{-1}\right)$ of the C19:0 solution

VIS = volume of the C19:0 solution added to sample $\mathrm{m}=$ mass of the FAEEs sample $(\mathrm{mg})$

\section{Results and Discussion}

\subsection{Physicochemical characterization of the stannosilicates}

The XRD patterns of the stannosilicates synthesized according to sol-gel chemical compositions detailed in
Tab. 1 are shown in Fig. 1a. The stannosilicate I presented a XRD pattern characteristic of a crystalline material and has structural similarity with the stannosilicate $\mathrm{AV}-10^{54}$. The stannosilicate AV-10 has an orthorhombic unit cell ( $\mathrm{a}=7.945 \AA$, b = 10.344 $\AA$ and $\mathrm{c}=11.625 \AA$ ) and its gel composition $\left(8.5 \mathrm{Na}_{2} \mathrm{O}: 5.4 \mathrm{SiO}_{2}: 1.0 \mathrm{SnO}_{2}: 115 \mathrm{H}_{2} \mathrm{O}\right)$ contained lowest $\mathrm{SiO}_{2}: \mathrm{Na}_{2} \mathrm{O}$ ratio $(\approx 0.6)$ in comparison with stannosilicate I $(\approx 4.0)$. X-ray diffraction patterns of stannosilicate II (gel composition of $2 \mathrm{Na}_{2} \mathrm{O}: \mathrm{Sn}_{2} \mathrm{O}: 4 \mathrm{SiO}_{2}: 80 \mathrm{H}_{2} \mathrm{O}$ ) indicate the formation of a new microporous material (XRD pattern not reported previously), while the stannosilicate $\mathrm{V}$ (gel composition of $\left.5 \mathrm{Na}_{2} \mathrm{O}: \mathrm{Sn}_{2} \mathrm{O}: 10 \mathrm{SiO}_{2}: 80 \mathrm{H}_{2} \mathrm{O}\right)$ is similar to phase $\mathrm{L}^{46}$. The effects of the sol-gel composition were observed in the crystallization of these materials. The experimental evidences indicated that $\mathrm{SiO}_{2}: \mathrm{Na}_{2} \mathrm{O}$ ratio in the range of $5-10$, as the ones used for the syntheses of stannosilicates III $\left(2 \mathrm{Na}_{2} \mathrm{O}: \mathrm{Sn}_{2} \mathrm{O}: 10 \mathrm{SiO}_{2}: 80 \mathrm{H}_{2} \mathrm{O}\right)$ and stannosilicates IV $\left(1 \mathrm{Na}_{2} \mathrm{O}: \mathrm{Sn}_{2} \mathrm{O}: 10 \mathrm{SiO}_{2}: 80 \mathrm{H}_{2} \mathrm{O}\right)$, induce the formation of tin oxide, clearly noticed in the XRD pattern of the stannosilicate III (Fig. 1a), as most of diffraction peaks were assigned to the $\mathrm{SnO}_{2}$ phase (JCPDS 41-1445).
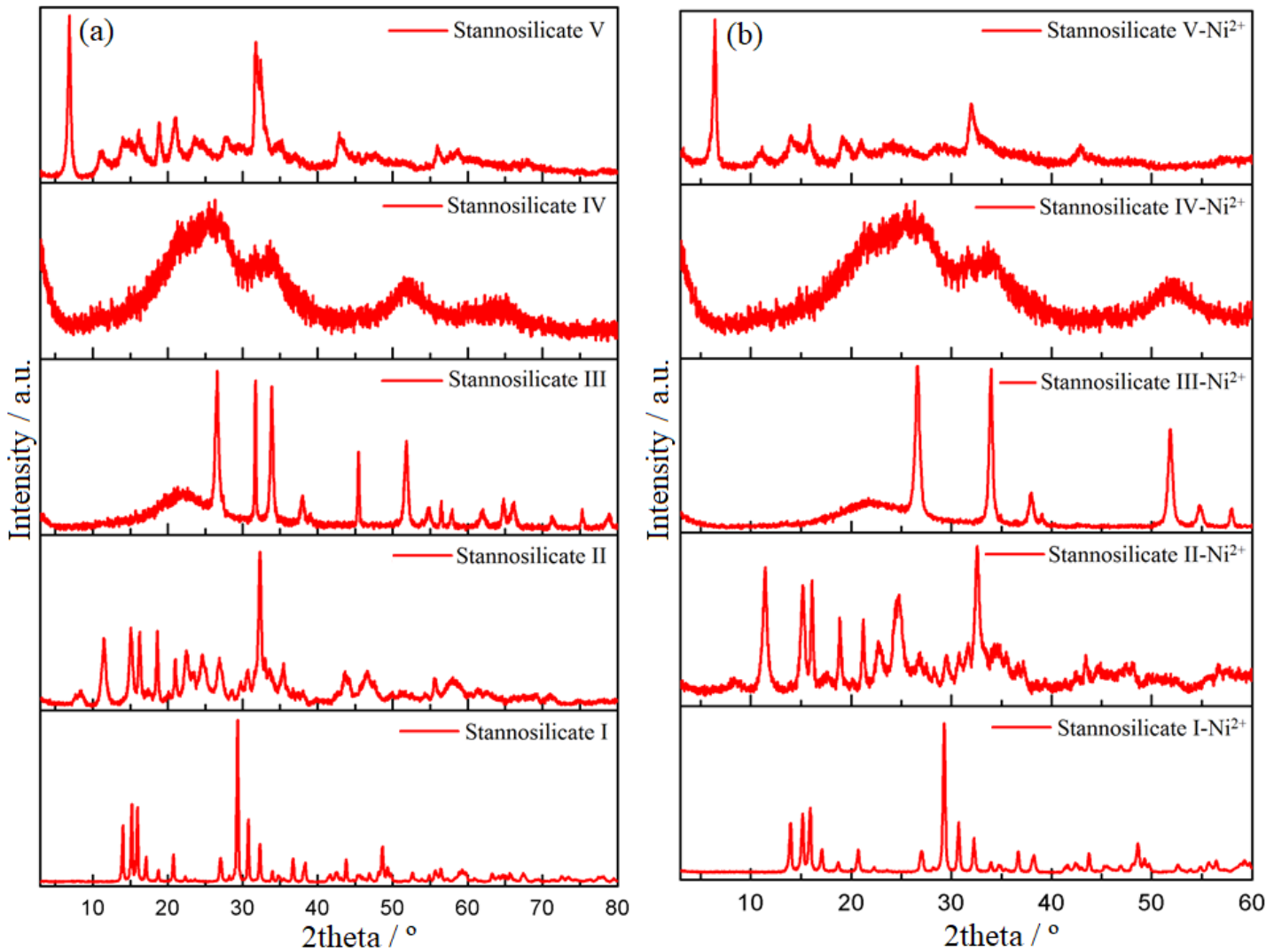

Figure 1. X-ray powder diffraction patterns of metallo-stannosilicates (a) before and (b) after the nickel ionexchange experiments (a.u. = arbitrary units). 
The ${ }^{29} \mathrm{Si}$ Single-Pulse MAS NMR results are shown in Fig. 2. The result for stannosilicate I (spectrum not shown) is similar to reported for stannosilicate AV$10^{54}$. The spectrum presents two resonances lines with chemical shift positions at $\delta_{1}=-87.0 \mathrm{ppm}$ and $\delta_{2}=-$ $88.7 \mathrm{ppm}$ with relative intensities of $1: 2$ and are associated with the $\mathrm{Si}(2 \mathrm{Si}, 2 \mathrm{Sn})$ environment. This similarity between both materials was proved recently by our research group ${ }^{55}$ in a solid-state NMR study, where the stannosilicate I was used as a model compound for developing a solid-state NMR strategy to verify the connectivity of $\mathrm{SiO}_{4}$ and $\mathrm{SnO}_{6}$ polyhedral, despite the very low natural abundances of $4.68 \%$ for ${ }^{29} \mathrm{Si}$ and $8.59 \%$ for ${ }^{29} \mathrm{Si}$ and ${ }^{119} \mathrm{Sn}$ nuclei, respectively. The ${ }^{29} \mathrm{Si}\left\{{ }^{119} \mathrm{Sn}\right\}$ and ${ }^{119} \mathrm{Sn}\left\{{ }^{29} \mathrm{Si}\right\}$ REDOR (rotationalecho double-resonance) NMR, ${ }^{29} \mathrm{Si}\left\{{ }^{1{ }^{19}} \mathrm{Sn}\right\}$ and ${ }^{119} \mathrm{Sn}\left\{{ }^{29} \mathrm{Si}\right\}$ REPT-HMQC (recoupled polarization transfer-heteronuclear multiple-quantum correlation) NMR and 2D ${ }^{29} \mathrm{Si}$ INADEQUATE NMR experiments using the crystallographic data of the sodium stannosilicate AV-10 (chemical composition $\mathrm{Na}_{2} \mathrm{SnSi}_{3} \mathrm{O}_{9} \cdot 2 \mathrm{H}_{2} \mathrm{O}$ ) proved that both stannosilicates consist of the same materials.
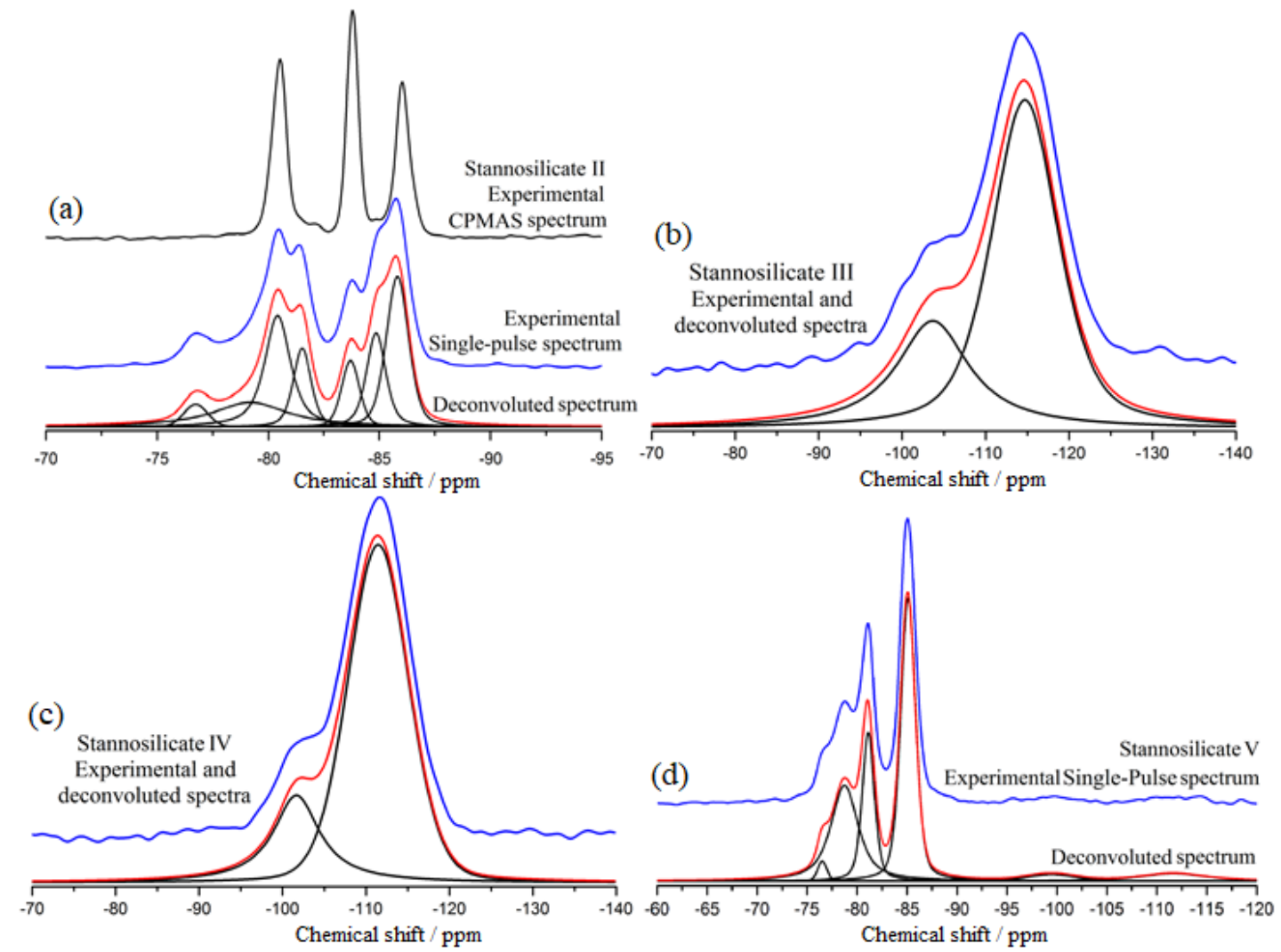

Figure 2. ${ }^{29} \mathrm{Si}$ single-pulse MAS NMR spectra of stannosilicates II, III, IV and V.

The ${ }^{29} \mathrm{Si}$ single-pulse MAS NMR spectra for the stannosilicates II, III, IV and V can be analyzed based in the seminal researches for ${ }^{29} \mathrm{Si}$ solid-state MAS NMR of aluminosilicates structures ${ }^{56,57}$. Deconvolution of the spectrum for the stannosilicate II have resulted in seven resonance lines with the following chemical shifts values: $\delta_{1}=-76.7 \mathrm{ppm}, \delta_{2}=-79.1 \mathrm{ppm}, \delta_{3}=-$ $80.4 \mathrm{ppm}, \delta_{4}=-81.5 \mathrm{ppm}, \delta_{5}=-83.7 \mathrm{ppm}, \delta_{6}=-84.8$ ppm and $\delta_{7}=-85.8 \mathrm{ppm}$. The ${ }^{29} \mathrm{Si}$ single-pulse MAS NMR spectrum for the stannosilicate III showed two resonances lines with chemical shifts at $\delta_{1}=-102.2$ ppm and $\delta_{2}=-111.4 \mathrm{ppm}$, which are associated to the $\mathrm{Si}(3 \mathrm{Si}, 1 \mathrm{Sn})$ and $\mathrm{Si}(4 \mathrm{Si})$ environments, respectively.
The stannosilicate IV showed a spectrum with two resonance lines at $\delta_{1}=-101.9 \mathrm{ppm}$ and $\delta_{2}=-111.4$ ppm positions. The ${ }^{29} \mathrm{Si}$ single-pulse MAS NMR spectrum for the stannosilicate $\mathrm{V}$ shows six resonance lines with the following chemical shift values: $\delta_{1}=$ $76.4 \mathrm{ppm}, \delta_{2}=-78.7 \mathrm{ppm}, \delta_{3}=-81.0 \mathrm{ppm}, \delta_{4}=-85.0$ ppm, $\delta_{5}=-99.4 \mathrm{ppm}$ and $\delta_{6}=-111.6 \mathrm{ppm}$. The results in the chemical shift range from $\delta=-97.1 \mathrm{ppm}$ to $\delta=-$ $111.6 \mathrm{ppm}$ are associated to the $\mathrm{Si}(3 \mathrm{Si}, 1 \mathrm{Sn})$ and $\mathrm{Si}(4 \mathrm{Si})$ environments.

The ${ }^{119} \mathrm{Sn}$ single-pulse MAS NMR spectra are shown in Fig. 3. The stannosilicate III presents a chemical shift at the position of $\delta=-604 \mathrm{ppm}$, 
therefore confirming the formation of a pure $\mathrm{SnO}_{2}$ phase ${ }^{14}$. The stannosilicates IV presented weak ${ }^{119} \mathrm{Sn}$ MAS NMR signals (spectra not shown). The ${ }^{119} \mathrm{Sn}$ single-pulse MAS NMR spectra of the stannosilicates
I, II and $\mathrm{V}$ have shown chemical shifts in the range from $\delta=-660 \mathrm{ppm}$ to $\delta=-720 \mathrm{ppm}$, which are assigned to the tin species in the $\mathrm{Sn}^{4+}$ oxidation state $^{58,59}$.

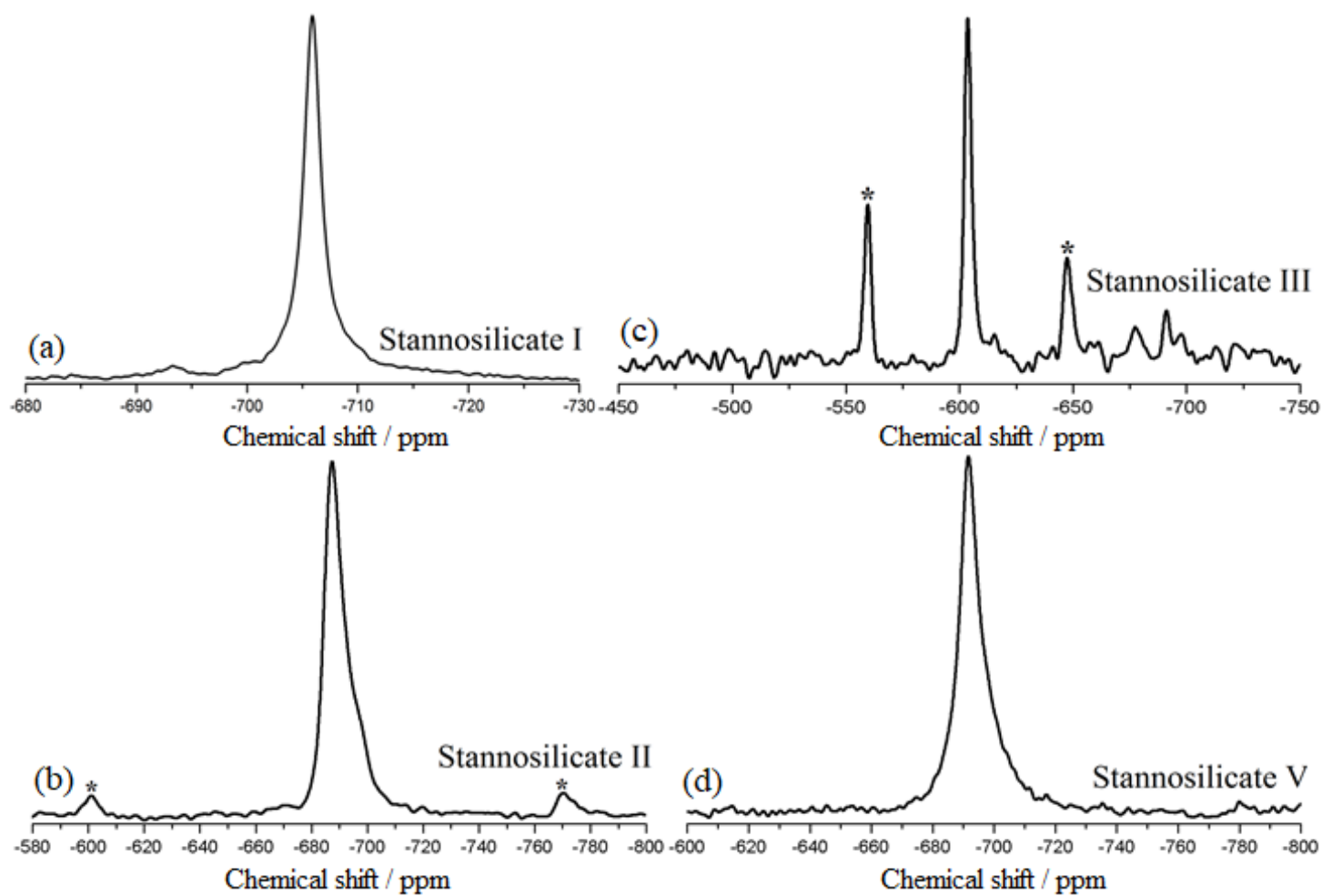

Figure 3. ${ }^{119} \mathrm{Sn}$ single-pulse MAS NMR spectra of stannosilicates I, II, III and V (*spinning sidebands, MAS frequency of $12.5 \mathrm{kHz}$ ).

Surface area results obtained by BET- $\mathrm{N}_{2}$ isotherms are shown in Tab. 1. The materials have low surface areas and maximum values were observed for the stannosilicates III and IV (86.95-and $50.45 \mathrm{~m}^{2} \mathrm{~g}^{-1}$, respectively), which are similar to the values reported in the literature for the $\mathrm{SnO}_{2}$ nanoparticles synthesized by different methods ${ }^{60-62}$. The morphology of the stannosilicates is shown in Figs. 4 and 5. The crystalline stannosilicate I (Fig. 4a) consist of micrometric plates with dimensions of $2 \times 1 \times 0.2 \mu \mathrm{m}$. The stannosilicates II and V (Fig. $4 \mathrm{~b}$ and $4 \mathrm{c}$, respectively) are built up by micrometric plates, while an aggregate of spherical particles with particles size smaller than $100 \mathrm{~nm}$ were observed for stannosilicates III and IV (Fig. 5a and 5b, respectively).

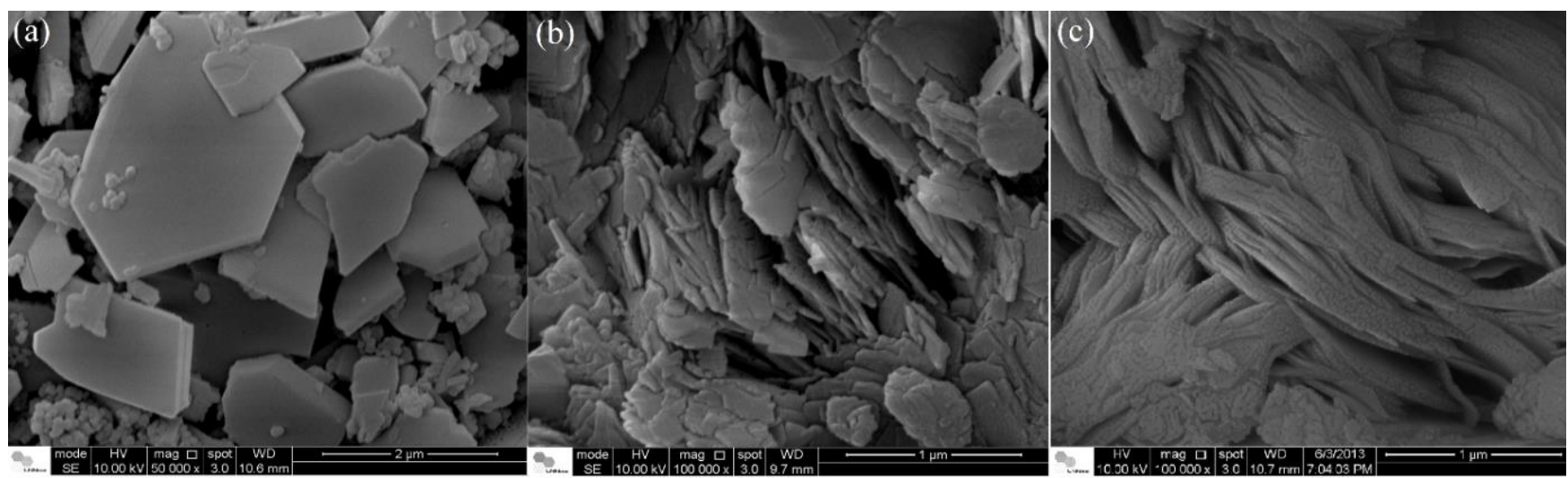

Figure 4. Scanning electron microscope-images of stannosilicates (a) I, (b) II and (c) V. 

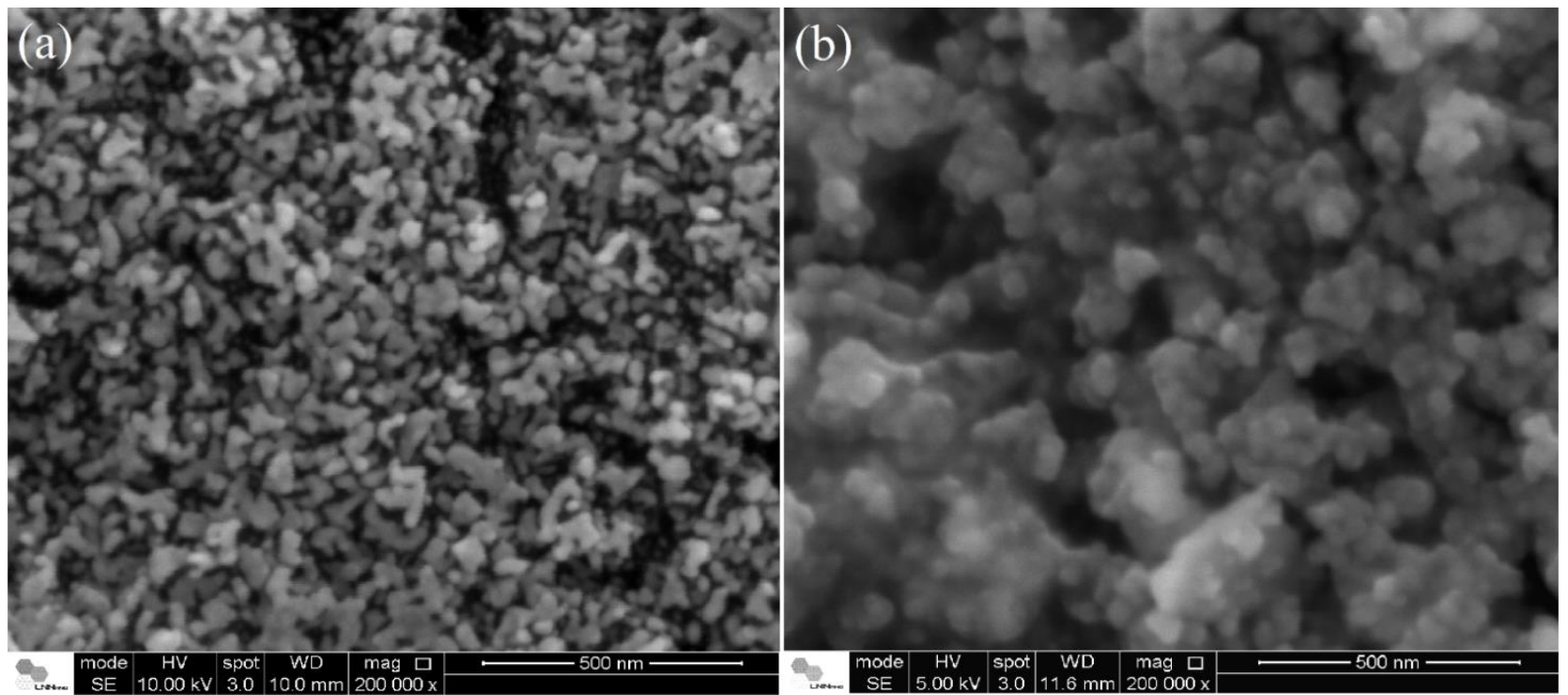

Figure 5. Scanning electron microscope images of stannosilicates (a) III and (b) IV.

\subsection{Enzymes immobilization and enzymatic activity of the stannosilicate-enzymes complexes}

Prior to the enzyme immobilization, the stannosilicates were submitted to nickel ion-exchange reactions. The important role played by nickel in enzymes immobilization and enzymatic activity has been reported previously ${ }^{34,35}$ and was also observed here for the stannosilicates supports nickel-exchanged. The amount of $\mathrm{Ni}^{2+}$ incorporated on the stannosilicates were determined by EDS analyses and the results are shown in Tab. 2. The nickel ion-exchange reactions have not caused significative changes in the stannosilicates structures (Fig. 1b). The zeta potential measurements of the as-made stannosilicates and the nickel-stannosilicates are also presented in Tab. 2 and the results showed an increase in the surface charge after the nickel-exchange reactions (except for the stannosilicate III, which presented the lowest amount of nickel), as well as the percentual of immobilized enzymes (Tab. 3). The enzymatic activity of stannosilicates-enzymes complexes is also presented in Tab. 3: the as-made stannosilicate III enzymes and stannosilicate $\mathrm{IV}^{-} \mathrm{Ni}^{2+}$-enzymes presented the highest enzymatic activities of $52.3 \pm 3.8$ and $58.0 \pm$ $3.2 \mathrm{U} \mathrm{mg}^{-1}$, respectively.

Table 2. Zeta potential (before and after nickel ion-exchange experiments) for the metallo-stannosilicates synthesized and nickel composition determined by energy dispersive X-ray spectroscopy (EDS).

\begin{tabular}{|l|c|c|c|c|}
\hline Stannosilicate & Zeta potencial / mV & Stannosilicate & Zeta potencial / $\mathbf{~ V V}$ & Nickel / \% \\
\hline I & $-34 \pm 5$ & ${\mathrm{I}-\mathrm{Ni}^{2+}}^{2+}$ & $-12 \pm 4$ & $0.5 \pm 0.1$ \\
\hline II & $-44 \pm 6$ & $\mathrm{II}^{2} \mathrm{Ni}^{2}$ & $-7 \pm 2$ & $4.5 \pm 0.1$ \\
\hline III & $7 \pm 4$ & $\mathrm{III}-\mathrm{Ni}^{2+}$ & $-18 \pm 4$ & $<0.2$ \\
\hline IV & $-40 \pm 6$ & $\mathrm{IV}^{2}-\mathrm{Ni}^{2+}$ & $-19 \pm 3$ & $0.4 \pm 0.1$ \\
\hline V & $-58 \pm 6$ & ${\mathrm{~V}-\mathrm{Ni}^{2+}}^{2+}$ & $-17 \pm 3$ & $6.3 \pm 0.1$ \\
\hline
\end{tabular}

Table 3. Percentage of Thermomyces lanuginosus lipase immobilized on the as-made stannosilicates and stannosilicates-nickel materials. In the table also are presented the enzymatic activity results for the as-made stannosilicates-enzymes and stannosilicates- $\mathrm{Ni}^{2+}$-enzymes complexes.

\begin{tabular}{|c|c|c|c|c|c|}
\hline Stannosilicate & $\begin{array}{c}\text { Enzyymes } \\
\text { immobilized / \% }\end{array}$ & $\begin{array}{c}\text { Enzymatic activity } \\
\qquad / \mathrm{U} \mathrm{mg}^{-1}\end{array}$ & Stannosilicate & $\begin{array}{c}\text { Enzymes } \\
\text { immobilized / \% }\end{array}$ & $\begin{array}{c}\text { Enzymmatic } \\
\text { activity } / \mathrm{U} \mathrm{mg}^{-1}\end{array}$ \\
\hline I & $28 \pm 10$ & $2.4 \pm 0.6$ & $\mathrm{I}-\mathrm{Ni}^{2+}$ & $29 \pm 9$ & $32 \pm 9$ \\
\hline II & $7.1 \pm 0.9$ & $1.0 \pm 0.4$ & $\mathrm{II} \mathrm{Ni}^{2+}$ & $33 \pm 4$ & $21 \pm 3$ \\
\hline III & $63 \pm 10$ & $52 \pm 4$ & III-Ni ${ }^{2+}$ & $82 \pm 6$ & $42 \pm 3$ \\
\hline IV & $39 \pm 16$ & $43 \pm 8$ & $\mathrm{IV}^{-\mathrm{Ni}^{2+}}$ & $36 \pm 2$ & $58 \pm 3$ \\
\hline V & $5 \pm 2$ & $1.6 \pm 0.1$ & $\mathrm{~V}-\mathrm{Ni}^{2+}$ & $42 \pm 7$ & $28 \pm 3$ \\
\hline
\end{tabular}


3.3 Fatty acid ethyl esters production by transesterification of refined palm oil (Elaeis guineensis) using stannosilicates and stannosilicates-enzymes heterogeneous catalysts complexes

Fatty acid ethyl esters yields obtained in the heterogeneous transesterification of refined palm oil (Elaeis guineensis) are shown in the Tab. 4. The asmade stannosilicates I, III and IV have shown no catalytic activity (FAEEs yields below 5\%), while the catalytic conversion of triacylglycerides using the stannosilicates II $(\mathrm{Na}: \mathrm{Sn}=2.0 \pm 0.2)$ and $\mathrm{V}(\mathrm{Na}: \mathrm{Sn}=$ $4.1 \pm 0.7)$ have yielded $28.3 \pm 0.2 \%$ and $60.8 \pm 0.5 \%$, respectively. The FAEEs yields using the stannosilicates- $\mathrm{Ni}^{2+}$-enzymes complexes as enzymatic catalysts are also presented in Tab. 4. The triacylglycerides conversion into FAEEs using the stannosilicates- $\mathrm{Ni}^{2+}$-enzymes complexes I, III and IV have yielded the following amounts of FAEEs: stannosilicate I $\mathrm{Ni}^{2+}$ enzyme $63.3 \pm 0.7 \%$, stannosilicate III $\mathrm{Ni}^{2+}$ enzyme $39.9 \pm 0.3 \%$ and stannosilicate $\mathrm{IV}-\mathrm{Ni}^{2+}$-enzyme $38.5 \pm 0.7 \%$. An example of gas chromatogram (GC-FID) for the highest FAEEs conversion (stannosilicate $\mathrm{I} \mathrm{Ni}^{2+}$ enzyme as biocatalyst) is illustrated in the supplementary material. It should be noticed that these metallo-stannosilicates in their as-made forms have shown no catalytic activity, nevertheless these positive catalytic results indicate their possible application as solid matrixes for enzymes immobilization.

The results indicated that the highest yield of FAEEs was obtained for the stannosilicate $\mathrm{I} \mathrm{Ni}^{2+}$ enzyme complex, which has $29 \pm 9 \%$ of enzymes immobilized. In order to verify the possible occurrence of a synergistic effect as reported by other authors ${ }^{34,35}$, the equivalent amount of enzyme immobilized on this catalyst was used in its free form in the transesterification of refined palm oil (Elaeis guineensis) under the same experimental condition. The FAEEs yield of $6.3 \pm 0.3 \%$ obtained in this reaction is a clear evidence of a synergistic effect among the nickel-stannosilicates used as inorganic supports and the Thermomyces lanuginosus lipase applied in transesterification reactions for biodiesel production.

Table 4. Results for the FAEEs yields by the transesterification of refined palm oil (Elaeis guineensis) using the asmade stannosilicates and stannosilicate- $\mathrm{Ni}^{2+}$-enzymes complexes as heterogeneous catalysts.

\begin{tabular}{|l|c|c|c|}
\hline As-made stannosilicates* & FAEEs yield / \% & Stannosilicate-enzymes complexes*** & FAEEs yield / \% \\
\hline I & $<5.0$ & I-Ni $^{2+}$-enzymes & $63.3 \pm 0.7^{* * *}$ \\
\hline II & $28.3 \pm 0.2$ & $\mathrm{II}^{*} \mathrm{Ni}^{2+}$-enzymes & $44.6 \pm 0.5$ \\
\hline III & $<5.0$ & $\mathrm{III}^{2} \mathrm{Ni}^{2+}$-enzymes & $39.9 \pm 0.3$ \\
\hline IV & $<5.0$ & $\mathrm{IV}^{2} \mathrm{Ni}^{2+}$-enzymes & $38.5 \pm 0.7$ \\
\hline V & $60.8 \pm 0.5$ & ${\mathrm{~V}-\mathrm{Ni}^{2+} \text {-enzymes }}$ & $42.5 \pm 0.6$ \\
\hline
\end{tabular}

*Experimental conditions: reactions were made in an open glass reactor (reflux condenser), temperature $=100{ }^{\circ} \mathrm{C}$, oil:alcohol molar ratio $=1: 30$, time of reaction $=12 \mathrm{~h}$ and amount of catalyst $=3 \%$ of catalyst referred to oil mass;

**Experimental conditions: reactions were made in $10 \mathrm{~mL}$ flasks, temperature $=40 \pm 2{ }^{\circ} \mathrm{C}$, time of reaction $=48 \mathrm{~h}$, oil:alcohol molar ratio $=1: 4$ and amount of catalyst $=5 \%$ referred to oil mass;

$* * *$ FAEEs yield for the amount of free enzyme immobilized on this support $(29 \pm 9 \%)$ applied in catalytic reaction $=6.3 \pm$ $0.3 \%$.

\section{Conclusions}

Several metallo-stannosilicates were synthesized and characterized by XRD, SEM, BET-N ${ }_{2}$ surface area and solid-state MAS NMR $\left({ }^{29} \mathrm{Si}\right.$ and ${ }^{119} \mathrm{Sn}$ nuclei) techniques. These materials were studied as potential inorganic solid matrixes for immobilization of Thermomyces lanuginosus lipase and also as heterogeneous catalysts in the transesterification of refined palm oil (Elaeis guineensis) by ethanolysis reactions. The results were promising, since that asmade and nickel-exchanged stannosilicates were able to immobilize from $5 \pm 2 \%$ to $82 \pm 6 \%$ of enzymes and presented enzymatic activity varying from $1.0 \pm 0.4 \mathrm{U} \mathrm{mg}^{-1}$ to $58 \pm 3 \mathrm{U} \mathrm{mg}^{-1}$. Some of these as-made materials, when applied as heterogeneous catalysts, presented no catalytic activity. However, when applied as biocatalysts in enzymatic transesterification reactions, stannosilicate- $\mathrm{Ni}^{+2}$ enzymes produced FAEEs yields varying from $38.5 \pm$ $0.7 \%$ to $63.3 \pm 0.7 \%$. These results are an evidence of a synergistic effect among the stannosilicates and enzymes, contributing to the advancement of research in the field of biodiesel production since these results were not reported previously for this class of mixed framework oxides. 


\section{Acknowledgments}

We thank the State of São Paulo Research Foundation (FAPESP) and National Council for Scientific and Technological Development $(\mathrm{CNPq})$ for the grant awards No. \#11/51851-5 and No. \#406761/2013-2, respectively. D.A.S. thanks CAPES (Proc. No. BEX 2428/15-6) and CNPq (Proc. No.142029/2012-2) for his fellowships. We acknowledge Mr. Carsten Prinz and Ms. Annett Zimathies (BAM Federal Institute for Materials Research and Testing, Division 1.3. Structure Analyses) for the BET-N ${ }_{2}$ measurements. We appreciate the assistance of Dr. Carlos A. O. Ramirez and Dr Jefferson Bettini (Brazilian National Laboratory of Nanotecnology, LNNano) for the analysis of SEMEDS. We also thank Prof. Dr. Christian Jäger (BAM Federal Institute for Materials Research and Testing, Division 1.3. Structure Analyses) for the Solid-State MAS NMR experiments and Prof. Dra. Marcia P. dos Santos Cabrera (São Paulo State University, IBILCE) for the Zeta Potential Measurements.

\section{References}

[1] Singh, S. P., Singh, D., Biodiesel production through the use of different sources and characterization of oils and their esters as the substitute of diesel: A review, Renewable and Sustainable Energy Reviews 14 (1) (2010) 200-216. https://doi.org/10.1016/j.rser.2009.07.017.

[2] Balat, M., Potential alternatives to edible oils for biodiesel production - A review of current work, Energy Conversion and Management 52 (2) (2011) 1479-1492. https://doi.org/10.1016/j.enconman.2010.10.011.

[3] Gui, M. M., Lee, K. T., Bhatia, S., Feasibility of edible oil vs. non-edible oil vs. waste edible oil as biodiesel feedstock, Energy $33 \quad$ (11) (2008) 1646-1653. https://doi.org/10.1016/j.energy.2008.06.002.

[4] Mekhilef, S., Siga, S., Saidur, R., A review on palm oil biodiesel as a source of renewable fuel, Renewable and Sustainable Energy Reviews 33 (4) (2011) 1937-1949. https://doi.org/10.1016/j.rser.2010.12.012.

[5] Issariyakul, T., Dalai, A. K., Biodiesel from vegetable oils, Renewable and Sustainable Energy Reviews 31 (2014) 446-471. https://doi.org/10.1016/j.rser.2013.11.001.

[6] Semwal, S., Arora, A. K., Badoni, R. P., Tuli, D. K., Biodiesel production using heterogeneous catalysts, Bioresource Technology 102 (3) (2011) 2151-2161. https://doi.org/10.1016/j.biortech.2010.10.080.

[7] Chouhan, A. P. S., Sarma, A. K., Modern heterogeneous catalysts for biodiesel production: A comprehensive review,
Renewable and Sustainable Energy Reviews 15 (9) (2011) 4378-4399. https://doi.org/10.1016/j.rser.2011.07.112.

[8] Sakai, T., Kawashima, A., Koshikawa, T., Economic assessment of batch biodiesel production processes using homogeneous and heterogeneous alkali catalysts, Bioresource Technology 100 (13) (2009) 3268-3276. https://doi.org/10.1016/j.biortech.2009.02.010.

[9] Lam, M. K., Lee, K. T., Mohamed, A. R., Homogeneous, heterogeneous and enzymatic catalysis for transesterification of high free fatty acid oil (waste cooking oil) to biodiesel: A review, Biotechnology Advances 28 (4) (2010) 500-518. https://doi.org/10.1016/j.biotechadv.2010.03.002.

[10] Dossin, T. F., Reyniers, M.-F., Berger, R. J., Marin, G. B., Simulation of heterogeneously $\mathrm{MgO}$-catalyzed transesterification for fine-chemical and biodiesel industrial production, Applied Catalysis B: Environmental 67 (1-2) (2006)

136-148. https://doi.org/10.1016/j.apcatb.2006.04.008.

[11] Corcoran, E. W., Vaughan, D. E. W., Eberly Junior, P. E., Efird, K. D., Substituted stannosilicates, their preparation and use as natural gas purification agents (C-2668), US 5 $264193 \quad$ A, 1993. https://patents.google.com/patent/US5264193A/en.

[12] Janiszewska, E., Kowalak, S., Supronowicz, W., Roessner, F., Synthesis and properties of stannosilicates, Microporous and Mesoporous Materials 117 (1-2) (2009) 423-430. https://doi.org/10.1016/j.micromeso.2008.07.032.

[13] Li, P., Liu, G., Wu, H., Liu, Y., Jiang, J.-G., Wu, P., Postsynthesis and Selective Oxidation Properties of Nanosized Sn-Beta Zeolite, The Journal Physical Chemistry $\begin{array}{lllll}\text { C } & 115 & \text { (9) } & \text { (2011) 3663-3670. }\end{array}$ https://doi.org/10.1021/jp1076966.

[14] Moliner, M., Román-Leshkov, Y., Davis, M. E., Tincontaining zeolites are highly active catalysts for the isomerization of glucose in water, Proceedings of the National Academy of Sciences of the United States of $\begin{array}{lllll}\text { America } & 107 & \text { (14) (2010) 6164-6168. }\end{array}$ https://doi.org/10.1073/pnas.1002358107.

[15] Román-Leshkov, Y., Moliner, M., Labinger, J. A., Davis, M. E., Mechanism of Glucose Isomerization Using a Solid Lewis Acid Catalyst in Water, Angewandte Chemie International Edition 49 (47) (2010) 8954-8957. https://doi.org/10.1002/anie.201004689.

[16] da Silva, D. A., Santisteban, O. A. N., de Vasconcellos, A., Paula, A. S., Aranda, D. A. G., Giotto, M. V., Jaeger, C., Nery, J. G., Metallo-stannosilicate heterogeneous catalyst for biodiesel production using edible, non-edible and waste oils as feedstock, Journal of Environmental Chemical

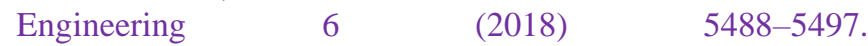
https://doi.org/10.1016/j.jece.2018.08.047. 
[17] Abreu, F. R., Lima, D. G., Hamú, E. H., Einloft, S., Rubim, J. C., Suarez, P. A. Z., New metal catalysts for soybean oil transesterification, Journal of the American Oil $\begin{array}{lllll}\text { Chemists' Society } 80 & \text { (6) (2003) 601-604. }\end{array}$ https://doi.org/10.1007/s11746-003-0745-6.

[18] Ferreira, D. A. C., Meneghetti, M. R., Meneghetti, S. M. P., Wolf, C. R., Methanolysis of soybean oil in the presence of tin(IV) complexes, Applied Catalysis A: General 317 (1) (2007) 58-61. https://doi.org/10.1016/j.apcata.2006.10.002.

[19] Serra, T. M., de Mendonça, D. R., da Silva, J. P. V., Meneghetti, M. R., Plentz Meneghetti, S. M. P., Comparison of soybean oil and castor oil methanolysis in the presence of tin(IV) complexes, Fuel. 90 (6) (2011) 2203-2206. https://doi.org/10.1016/j.fuel.2011.02.027.

[20] Xie, W., Wang, H., Li, H., Silica-Supported Tin Oxides as Heterogeneous Acid Catalysts for Transesterification of Soybean Oil with Methanol, Industrial \& Engineering Chemistry Research $51 \quad$ (1) (2012) 225-231. https://doi.org/10.1021/ie202262t.

[21] Abreu, F. R., Lima, D. G., Hamú, E. H., Wolf, C., Suarez, P. A., Utilization of metal complexes as catalysts in the transesterification of Brazilian vegetable oils with different alcohols, Journal of Molecular Catalysis A: $\begin{array}{llll}\text { Chemical } & 209 & (1-2) & \text { (2004) }\end{array}$ https://doi.org/10.1016/j.molcata.2003.08.003.

[22] Casas, A., Ramos, M. J., Rodríguez, J. F., Pérez, Á., Tin compounds as Lewis acid catalysts for esterification and transesterification of acid vegetable oils, Fuel Processing Technology $\quad 106 \quad$ (2013) 321-325. https://doi.org/10.1016/j.fuproc.2012.08.015.

[23] Lam, M. K., Lee, K. T., Mixed methanol-ethanol technology to produce greener biodiesel from waste cooking oil: A breakthrough for $\mathrm{SO}_{4}{ }^{2-} / \mathrm{SnO}^{2}-\mathrm{SiO}^{2}$ catalyst, Fuel Processing Technology $92 \quad$ (8) (2011) 1639-1645. https://doi.org/10.1016/j.fuproc.2011.04.012.

[24] Lam, M. K., Lee, K. T., Accelerating transesterification reaction with biodiesel as co-solvent: A case study for solid acid sulfated tin oxide catalyst, Fuel 89 (12) (2010) 38663870. https://doi.org/10.1016/j.fuel.2010.07.005.

[25] Bajaj, A., Lohan, P., Jha, P. N., Mehrotra, R., Biodiesel production through lipase catalyzed transesterification: An overview, Journal of Molecular Catalysis B: Enzymatic 62 (1) (2010) 9-14. https://doi.org/10.1016/j.molcatb.2009.09.018.

[26] Rosset, I. G., Tavares, M. C. H., Assaf, E. M., Porto, A. L. M., Catalytic ethanolysis of soybean oil with immobilized lipase from Candida antarctica and ${ }^{1} \mathrm{H}$ NMR and GC quantification of the ethyl esters (biodiesel) produced,
Applied Catalysis A: General 392 (1-2) (2011) 136-142. https://doi.org/10.1016/j.apcata.2010.10.035.

[27] Ferreira, I. M., Ganzeli, L. de S., Rosset, I. G., Yoshioka, S. A., Porto, A. L. M., Ethylic Biodiesel Production Using Lipase Immobilized in Silk FibroinAlginate Spheres by Encapsulation, Catalysis Letters 147 (2017) 269-280. https://doi.org/10.1007/s10562-016-1917-0.

[28] Rosset, I. G., Porto, A. L. M., Catálise Enzimática: Transesterificação do Óleo de Soja e Esterificação do Ácido Oleico via Lipases, Revista Brasileira de Energias $\begin{array}{llllll}\text { Renováveis } & 4 & \text { (2) } & \text { (2015) }\end{array}$ https://doi.org/10.5380/rber.v4i2.42288.

[29] Rosset, I. G., Cavalheiro, M. C. H. T., Assaf, E. M., Porto, A. L. M., Enzymatic Esterification of Oleic Acid with Aliphatic Alcohols for the Biodiesel Production by Candida antarctica Lipase, Catalysis Letters 143 (2013) 863-872. https://doi.org/10.1007/s10562-013-1044-0.

[30] Rosset, I. G., Assaf, E. M., Porto, A. L. M., Biocatalytic Production of Ethyl Esters (Biodiesel) by Enzymatic Transesterification from Synthetic Triolein, Current $\begin{array}{lllll}\text { Catalysis } & 2 & \text { (1) 53-61. }\end{array}$ https://doi.org/10.2174/2211544711302010009.

[31] Antczak, M. S., Kubiak, A., Antczak, T., Bielecki, S., Enzymatic biodiesel synthesis - Key factors affecting efficiency of the process, Renewable Energy 34 (5) (2009) 1185-1194. https://doi.org/10.1016/j.renene.2008.11.013.

[32] Jegannathan, K. R., Abang, S., Poncelet, D., Chan, E. S., Ravindra, P., Production of Biodiesel Using Immobilized Lipase-A Critical Review, Critical Reviews in

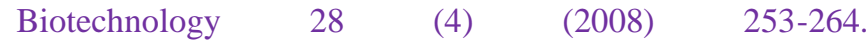
https://doi.org/10.1080/07388550802428392.

[33] Bergamasco, J., de Araujo, M. V., de Vasconcellos, A., Luizon Filho, R. A., Hatanaka, R. R., Giotto, M. V., Aranda, D. A. G., Nery, J. G., Enzymatic transesterification of soybean oil with ethanol using lipases immobilized on highly crystalline PVA microspheres, Biomass and $\begin{array}{llll}\text { Bioenergy } & 59 & \text { (2013) } & \text { 218-233. }\end{array}$ https://doi.org/10.1016/j.biombioe.2013.09.006.

[34] de Vasconcellos, A., Paula, A. S., Luizon Filho, R. A., Farias, L. A., Gomes, E., Aranda, D. A. G., Nery, J. G., Synergistic effect in the catalytic activity of lipase Rhizomисor miehei immobilized on zeolites for the production of biodiesel, Microporous and Mesoporous $\begin{array}{llll}\text { Materials } & 163 & \text { (2012) } & \text { 343-355. }\end{array}$ https://doi.org/10.1016/j.micromeso.2012.07.043.

[35] de Vasconcellos, A., Laurenti, J. B., Miller, A. H., da Silva, D. A., de Moraes, F. R., Aranda, D. A. G., Nery, J. G., Potential new biocatalysts for biofuel production: The fungal lipases of Thermomyces lanuginosus and Rhizomucor miehei immobilized on zeolitic supports ion exchanged with 
transition metals, Microporous and Mesoporous Materials 214 (2015)

166-180.

https://doi.org/10.1016/j.micromeso.2015.05.007.

[36] de Vasconcellos, A., Miller, A. H., Aranda, D. A. G., Nery, J. G., Biocatalysts based on nanozeolite-enzyme complexes: Effects of alkoxysilane surface functionalization and biofuel production using microalgae lipids feedstock, Colloids and Surfaces B: Biointerfaces 165 (2018) 150-157. https://doi.org/10.1016/j.colsurfb.2018.02.029.

[37] MacArio, A., Giordano, G., Setti, L., Parise, A., Campelo, J. M., Marinas, J. M., Luna, D., Study of lipase immobilization on zeolitic support and transesterification reaction in a solvent free-system, Biocatalysis and

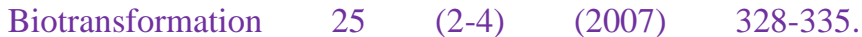
https://doi.org/10.1080/10242420701444256.

[38] Macario, A., Molimer, M., Diaz, U., Jorda, J. L., Corma, A., Giordano, G., Biodiesel production by immobilized lipase on zeolites and related materials, Studies in Surface Science and Catalysis 174 (Part B) (2008) 10111016. https://doi.org/10.1016/S0167-2991(08)80061-4.

[39] Brito, A., Borges, M. E., Otero, N., Zeolite Y as a Heterogeneous Catalyst in Biodiesel Fuel Production from Used Vegetable Oil, Energy \& Fuels 21 (6) (2007) 32803283. https://doi.org/10.1021/ef700455r.

[40] Costa, L., Brissos, V., Lemos, F., Ribeiro, F. R., Cabral, J. M. S., Enhancing the thermal stability of lipases through mutagenesis and immobilization on zeolites, Bioprocess and Biosystems Engineering $32 \quad$ (2009) 53-61. https://doi.org/10.1007/s00449-008-0220-x.

[41] Hölker, U., Höfer, M., Lenz, J., Biotechnological advantages of laboratory-scale solid-state fermentation with fungi, Applied Microbiology and Biotechnology 64 (2004) 175-186. https://doi.org/10.1007/s00253-003-1504-3.

[42] Verdugo, C., Luna, D., Posadillo, A., Sancho, E. D., Rodrígues, S., Bautista, F., Luque, R., Marinas, J. M., Romero, A. A., Production of a new second generation biodiesel with a low cost lipase derived from Thermomyces lanuginosus: Optimization by response surface methodology, Catalysis Today 167 (1) (2011) 107-112. https://doi.org/10.1016/j.cattod.2010.12.028.

[43] Du, W., Xu, Y.-Y., Liu, D.-H., Li, Z.-B., Study on acyl migration in immobilized lipozyme TL-catalyzed transesterification of soybean oil for biodiesel production, Journal of Molecular Catalysis B: Enzymatic 37 (1-6) (2005) 68-71. https://doi.org/10.1016/j.molcatb.2005.09.008.

[44] Zhang, W.-W.., Yang, X.-L., Jia, J.-Q., Wang, N., Hu, C.-L., Yu, X.-Q., Surfactant-activated magnetic cross-linked enzyme aggregates (magnetic CLEAs) of Thermomyces lanuginosus lipase for biodiesel production, Journal of
Molecular Catalysis B: Enzymatic 115 (2015) 83-89. https://doi.org/10.1016/j.molcatb.2015.02.003.

[45] Corcoran Junior, E. W., Vaughan, D. E. W., Hydrothermal synthesis of mixed octahedral-tetrahedral oxides: Synthesis and characterization of sodium stannosilicates, Solid State Ionics 32-33 (Part 1) (1989) 423429. https://doi.org/10.1016/0167-2738(89)90250-6.

[46] Corcoran Junior, E. W., Vaughan, D. E. W., Eberly, P. E., Stannosilicates and preparation thereof (C-2417), US 5 $110 \quad$ 571A, 1992. https://patents.google.com/patent/US5110571A/en.

[47] Brunauer, S., Emmett, P. H., Teller, E., Adsorption of Gases in Multimolecular Layers, Journal of the American Chemical Society $60 \quad$ (2) (1938) 309-319. https://doi.org/10.1021/ja01269a023.

[48] Cossement, C., Darville, J., Gilles, J.-M., Nagy, J. B., Fernandez, C., Amoureux, J.-P., Chemical shift anisotropy and indirect coupling in $\mathrm{SnO}_{2}$ and $\mathrm{SnO}$, Magnetic Resonance

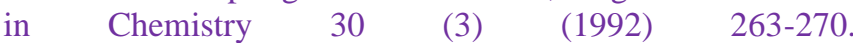
https://doi.org/10.1002/mrc.1260300313.

[49] Alkan, M., Demirbaş, Ö., Doğan, M., Electrokinetic properties of sepiolite suspensions in different electrolyte media, Journal of Colloid and Interface Science 281 (1) (2005) 240-248. https://doi.org/10.1016/j.jcis.2004.08.036.

[50] Hu, Y.-Y., Zhang, Y.-H., Ren, N., Tang, Y., Crystal Plane- and Size-Dependent Protein Adsorption on Nanozeolite, The Journal of Physical Chemistry C 113 (42) (2009) 18040-18046. https://doi.org/10.1021/jp903989p.

[51] Bradford, M. M., A rapid and sensitive method for the quantitation of microgram quantities of protein utilizing the principle of protein-dye binding, Analytical Biochemistry 72 (1-2) (1976) 248-254. https://doi.org/10.1016/00032697(76)90527-3.

[52] Ghiaci, M., Aghaei, H., Soleimanian, S., Sedaghat, M. E., Enzyme immobilization: Part 1. Modified bentonite as a new and efficient support for immobilization of Candida rugosa lipase, Applied Clay Science 43 (3-4) (2009) 289. 295. https://doi.org/10.1016/j.clay.2008.09.008.

[53] Gupta, P., Upadhyay, L. S. B., Shrivastava, R., Lipase Catalyzed-transesterification of Vegetable Oils by Lipolytic Bacteria, Research Journal of Microbiology 6 (3) (2011) 281-288. https://doi.org/10.3923/jm.2011.281.288.

[54] Ferreira, A., Lin, Z., Rocha, J., Morais, C. M., Lopes, M., Fernandez, C., Ab Initio Structure Determination of a Small-Pore Framework Sodium Stannosilicate, Inorganic

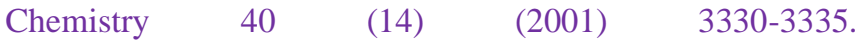
https://doi.org/10.1021/ic0012571. 
[55] da Silva, D. A., Greiser, S., Contro, J., Medeiros, V. L., Nery, J. G., Jaeger, C., ${ }^{1} \mathrm{H},{ }^{29} \mathrm{Si}$ and ${ }^{119} \mathrm{Sn}$ double and triple resonance NMR spectroscopy of the small-pore framework sodium stannosilicate $\mathrm{Na}_{2} \mathrm{SnSi}_{3} \mathrm{O}_{9} \cdot 2 \mathrm{H}_{2} \mathrm{O}$, Solid State Nuclear Magnetic Resonance $107 \quad$ (2020) 101661. https://doi.org/10.1016/j.ssnmr.2020.101661.

[56] Klinowski, J., Recent Advances in Solid-State NMR of Zeolites, Annual Review of Materials Science 18 (1988) 189-218.

https://doi.org/10.1146/annurev.ms.18.080188.001201.

[57] Fyfe, C. A., Feng, Y., Gondey, H., Kokotailo, G. T., Gies, H., One- and two-dimensional high-resolution solidstate NMR studies of zeolite lattice structures, Chemical $\begin{array}{llll}\text { Reviews } & 91 \quad \text { (7) (1991) 1525-1543. }\end{array}$ https://doi.org/10.1021/cr00007a013.

[58] Mal, N. K., Bhaumik, A., Kumar, R., Ramaswamy, A. V., Sn-ZSM-12, a new, large pore MTW type tin-silicate molecular sieve: synthesis, characterization and catalytic properties in oxidation reactions, Catalysis Letters 33 (1995) 387-394. https://doi.org/10.1007/BF00814240.

[59] Cruz, M., Morales, J., Espinos, J. P., Sanz, J., XRD, XPS and ${ }^{119}$ Sn NMR study of tin sulfides obtained by using chemical vapor transport methods, Journal of Solid State $\begin{array}{lllll}\text { Chemistry } & 175 & \text { (2) } & \text { (2003) 359-365. }\end{array}$ https://doi.org/10.1016/S0022-4596(03)00329-3.

[60] Song, K. C., Kang, Y., Preparation of high surface area tin oxide powders by a homogeneous precipitation method, Materials Letters $42 \quad$ (5) (2000) 283-289. https://doi.org/10.1016/S0167-577X(99)00199-8.

[61] Leite, E. R., Weber, I. T., Longo, E., Varela, J. A., A New Method to Control Particle Size and Particle Size Distribution of $\mathrm{SnO}_{2}$ Nanoparticles for Gas Sensor Applications, Advanced Materials 12 (13) (2000) 965-968. https://doi.org/10.1002/1521-

4095(200006)12:13\%3C965:AID-ADMA965\%3E3.0.CO;27.

[62] Song, K. C., Kim, J. H., Synthesis of high surface area tin oxide powders via water-in-oil microemulsions, Powder $\begin{array}{lllllll}\text { Technology } & 107 & \text { (3) } & \text { (2000) }\end{array}$ https://doi.org/10.1016/S0032-5910(99)00255-7. 